\title{
Quality characteristics of meat seasoning sauce containing fermented Oenothra biennis juice
}

\author{
Yoo-Bok Ahn, La-Young Park, Shin-Ho Lee* \\ Department of Food Science \& Technology, Catholic University of Daegu, Gyeongsan 38430, Korea
}

\section{달맞이꽃 발효액을 이용한 양념육 소스의 품질 특성}

\author{
안유복 · 박나영 - 이신호* \\ 대구가톨릭대학교 식품공학과
}

\begin{abstract}
The characteristics and quality changes of sauces containing different concentrations $(5,10$, and $15 \%)$ of fermented Oenothra biennis juice (FOBJ) were studied for its potential as a new meat seasoning suace. $\mathrm{pH}$ of the seasoning sauce was ranged from 5.23 to 5.37. Sugar content of seasoning sauces increased decreasing on increase of FOBJ concentration while the color $(\mathrm{L}, \mathrm{a}, \mathrm{b})$ decreased. DPPH radical scavenging ability and TBARS values of the seasoning sauce was increased significantly by the addition of FOBJ $(p<0.05)$. The total bacteria number of the seasoning sauces was approximately $3 \mathrm{log}$ CFU/g while coliform bacteria were not detected in all tested sauces. The sauce containing 5\% FOBJ showed the highest value in taste, color, overall acceptability among all tested sauces. The $\mathrm{pH}$ and titratable acidity of the meat seasoning sauces was not changed significantly during 25 days at $10^{\circ} \mathrm{C}$. The total bacteria number of the seasoning sauces was steadly 3.62 3.83 $\log \mathrm{CFU} / \mathrm{g}$ for 25 days at $10^{\circ} \mathrm{C}$. The number of coliform was not detected during storage periods. These results suggested the possibility of development of new meat seasoning sauce containing FOBI.
\end{abstract}

Key words : seasoned pork, Oenothera biennis, quality characteristics, seasoning sauce

\section{서 론}

소스(sauce)는 음식의 맛과 색상 개선을 위하여 사용되어 온 액체 또는 반 유동상의 조미료로써 '소금을 기본으로 한 조미용액'을 의미하는 라틴어의 'Salsa'에서 유래되었 다. 이러한 소스는 음식의 맛, 냄새 및 색상을 개선시켜 식옥증진과 영양가를 높이고 음식의 수분을 유지시켜주며 조리과정 중 재료들을 서로 결합시키는 역할을 한다 $(1,2)$ 양념육은 식육에 식염, 조미료, 향신료 등을 양념하고 냉장 또는 냉동한 것으로 식육 함량이 $60 \%$ 이상이어야 한다고 식품공전(KFDA, 2002)에 규정되어 있다(3). 이때 사용되는

*Corresponding author. E-mail : leesh@cu.ac.kr Phone : 82-53-850-3217, Fax : 82-53-850-3217

Received 27 April 2016; Revised 27 May 2016; Accepted 30 May 2016.

Copyright (c) The Korean Society of Food Preservation. All rights reserved.
양념은 맛 부여, 풍미 향상, 연육 효과, 조직감 부여, 보수력 증진, 이취 제거 등의 효과가 있다(4). 그러나 양념육은 품질 유지와 저장성을 향상시키기 위하여 BHA, BHT, propyl gallate 등의 합성 항산화제(5), sorbic acid 같은 합성 보존료 (6), 질산염 및 아질산염 같은 합성발색제(7) 등을 사용하고 있다. 그러나 이들의 유해성이 밝혀지면서 $(7,8)$, 소비자들 은 이를 기피하게 되고, 따라서 천연의 보존료나 항산화제 의 개발이 절실히 필요하게 되었다. 최근에는 웰빙(wellbeing) 지향 추세에 부응할 수 있는 기능성 식재료를 첨가한 불고기 소스의 개발 필요성이 대두되고 있으며, 그로 인해 현초(9), 오디(10), 오미자(11), 당귀 추출물(12) 그리고 울금 (13) 등 기능성 식재료를 첨가한 양념육 소스의 제조가 활발 히 진행되고 있다.

산야초 발효액은 야생에 존재하는 약용식물에 당을 첨가 한 후 숙성과정을 통해 제조되며, 이때 각종 식물 자체가 함유한 각종 효소가 활성화되어 발효과정을 거치는 동안 식물체의 성분들이 소화, 흡수되기 쉬운 형태로 전환된다 
(13), 달맞이꽃에는 불포화 오메가 지방산인 감마리놀렌산 ( -linolenic acid)을 비롯하여 리놀산(linoleic acid) 및 올레 익산(oleic acid)과 같은 성분들이 다량 포함되어 있어 항염 작용을 비롯한 고혈압, 항균, 항암과 같은 여러 활성을 나타 낸다고 알려져 있다(14). 따라서 본 연구는 산야초 발효액의 식품소재로써의 활용방안을 모색하기 위하여, 달맞이꽃 발 효액 첨가량을 달리한 양념육 소스의 품질특성과 저장성을 비교 검토하였다.

\section{재료 및 방법}

\section{달맞이꽃 발효액의 제조}

달맞이꽃(Oenothera biennis)은 대구 근교 야산에서 채취 하여 흐르는 물에 세척하여 물기를 제거한 후 사용하였으 며, 발효액 제조는 Lee 등(15)의 방법으로 달맞이꽃과 설탕 용액 $\left(50{ }^{\circ} \mathrm{Brix}\right)$ 을 $1: 2(\mathrm{w} / \mathrm{w})$ 비율로 첨가하여 $30^{\circ} \mathrm{C}$ 에서 10 일 동안 발효시킨 후 여과하여 $20^{\circ} \mathrm{C}$ 에서 1 개월 동안 숙성시킨 것을 사용하였다.

\section{소스의 제조}

소스 제조는 $\mathrm{Kim}$ 등(16)의 방법에 준하여 간장 $37.5 \mathrm{~g}$, 설탕 $16.25 \mathrm{~g}$, 후추 $0.375 \mathrm{~g}$, 굴 소스 $10 \mathrm{~g}$, worcester sauce $10 \mathrm{~g}$, 월계수 잎 $8.375 \mathrm{~g}$ 그리고, 물 $17.5 \mathrm{~g}$ 의 배합비로 제조하 여 대조구로 사용하였고, 제조된 소스에 달맞이꽃 발효액 을 각각 $5,10,15,20 \%(\mathrm{w} / \mathrm{w})$ 농도로 첨가하여 제조하였다.

\section{소스의 일반 성분 분석}

일반성분 분석은 $\mathrm{AOAC}$ 방법(17)에 따라 행하였다. 즉, 수분은 $105^{\circ} \mathrm{C}$ 상압건조가열법으로, 조단백질은 micro Kjeldahl 질소정량법으로, 조지방은 Soxhlet 추출법으로, 조회분은 $550^{\circ} \mathrm{C}$ 직접건식회화법으로, 조섬유는 Fiberetec system M(Tecator Co., Sweden)을 이용하여 Henneberg-Stohmann 개량법으로 분석하였다.

\section{$\mathrm{pH}$, 및 적정산도 측정}

$\mathrm{pH}$ 측정은 소스 $10 \mathrm{~g}$ 을 증류수 $90 \mathrm{~mL}$ 과 함께 homogenizer(Nissei, Nihonseiki Kaisha Ltd., Tokyo, Japan) 로 $10,000 \mathrm{rpm}$ 에서 1 분간 균질하여 시료로 사용하였으며, $\mathrm{pH}$ meter(Orion 410A, Orion Research Inc., Boston, USA)를 사용하여 측정하였다. 적정산도는 전처리한 시료에 $0.1 \mathrm{~N}$ $\mathrm{NaOH}$ 로 $\mathrm{pH}$ 8.3에 도달할 때까지의 소비량 $(\mathrm{mL})$ 을 환산하 였다.

\section{미생물수 측정}

시료 $1 \mathrm{~mL}$ 를 취한 후 $0.1 \%$ peptone수를 사용하여 각각의 시료를 적정 희석하여 총균수는 plate count agar(Difco Co., Detroit, MI, USA), 대장균군은 violet red bile agar(Difco
Co.)에 접종하여 $37^{\circ} \mathrm{C}$ 에서 24시간 배양한 후 나타난 colony 를 계수하여 $\mathrm{CFU} / \mathrm{g}$ 으로 나타내었다.

\section{색도 측정}

소스의 색차는 시료 $20 \mathrm{~g}$ 을 $5.2 \times 1.3 \mathrm{~cm}$ (직경×높이)의 투명 용기를 사용하였고, Hunter color difference meter(CR 200, Minolta, Kyoto, Japan)를 이용하여 명도(L, lightness), 적색도(a, redness), 황색도(b, yellowness) 값으로 측정하였 다. 이때 표준색은 $\mathrm{L}=94.95, \mathrm{a}=0.3132, \mathrm{~b}=0.3203$ 으로 하였 으며, 각 시료별 5 회 반복하여 평균값을 구하였다.

\section{유리당 측정}

시료 $5 \mathrm{~g}$ 를 취하여 3 차 증류수를 가하여 균질화시킨 다음 $50 \mathrm{~mL}$ 로 정용한 후 원심분리기(Centrifuge 5810R, Eppendorf, Hamburg, Germany)로 10 분간 4,000 rpm에서 원심분리한 후 상등액을 취하였다. 상등액은 $\mathrm{C}_{18} \mathrm{Sep}$-pak cartridge와 $0.45 \mu \mathrm{m}$ membrane filter로 통과시킨 것을 Waters 515 series HPLC system(Waters Co., Milford, CT, USA)으로 분석하였 다. 이때 HPLC 분석 조건으로 칼럼은 Sugar-pak ${ }^{\mathrm{TM}}$ I $(6.5 \times 300 \mathrm{~mm}$, Waters Co. $)$ 을 사용하였고, 용매는 HPLC용 증류수, 유속은 $0.4 \mathrm{~mL} / \mathrm{min}$ 으로 하였다. 유리당 함량은 시 료 중의 각 유리당과 동일한 표준물질(Sigma-Aldrich Co., St. Louis, MO, USA)을 이용하여 작성한 검량선으로부터 계산하였다.

$\mathrm{DPPH}$ 라디칼 소거능, 지방산패억제능 측정용 시료 조제

소스 $10 \mathrm{~g}$ 을 $70 \%$ ethanol $100 \mathrm{~mL}$ 에 가하여 실온에서 24 시간 추출한 후 $3,000 \mathrm{rpm}$ 에서 15 분간 원심분리하여 상 등액을 $0.45 \mu \mathrm{m}$ membrane filter로 여과하고 10 배 희석(0.1 $\mathrm{g} / \mathrm{mL}$ )하여 측정용 시료로 사용하였다.

\section{$\mathrm{DPPH}$ 라디칼 소거능 측정}

$\mathrm{DPPH}$ 라디칼 소거능 측정은 Blois의 방법(18)을 변형하 여 각 추출물 $0.4 \mathrm{~mL}$ 에 $0.4 \mathrm{mM} \mathrm{DPPH}(a, a$-diphenyl- $\beta$ -picrylhydrazyl, Sigma-Aldrich Co.) 에탄올 용액 $0.8 \mathrm{~mL}$ 을 진탕 혼합하고, 10 분간 방치 후 $525 \mathrm{~nm}$ 에서 흡광도를 측정 하였으며 계산식, DPPH radical scavenging ability(\%)= 100 -[(OD of sample/OD of control $) \times 100]$ 에 의하여 활성을 산출하였다.

\section{지방산패 억제효과(TBARS) 측정}

지방산패억제효과는 Buege와 Aust(19)의 thiobarbituric acid reactive substances(TBARS)방법을 변형하여 측정하였 다. 상온에서 추출물 $0.1 \mathrm{~mL}$, emulsion oil $0.5 \mathrm{~mL}$, 증류수 $0.3 \mathrm{~mL}$ 와 $\mathrm{Fe}^{2+}$ (산화촉진제) $0.1 \mathrm{~mL}$ 를 섞은 후 $37^{\circ} \mathrm{C}$ 에서 1시 간 반응시켰다. 반응 혼합물을 잘 섞은 다음 $2 \mathrm{~mL} \mathrm{TBA} / \mathrm{TCA}$ 시약을 가하고 다시 혼합 후 끓는 물에서 15 분간 가열시켰 
다. 가열 후 찬물에서 식힌 후 $3,000 \mathrm{rpm}$ 에서 10 분간 원심분 리 시킨 상등액을 $531 \mathrm{~nm}$,에서 흡광도를 측정하였고, 공시 료는 시료 대신에 증류수를 가하여 같은 방법으로 측정하였 으며 계산식, TBARS(Inhibition of lipid rancidity, \%)= 100 -[(OD of sample/OD of control $) \times 100]$ 에 의하여 활성을 산출하였다.

\section{관능검사}

관능검사는 식품을 전공하는 대학생 및 대학원생 20 명을 대상으로 색상, 조직감, 맛, 향기, 종합적 기호도를 5점 채점 법(아주 좋다 5점, 보통이다 3점, 아주 나쁘다 1점)으로 평가 하였다.

\section{통계처리}

색차와 관능검사를 제외한 모든 실험은 3회 반복으로 행하였으며, 평균치 간의 유의성은 SPSS system(Statistical Package for Social Sciences, IBM SPSS Inc., Chicago, IL, USA) software package(version 19.0)를 이용하여 통계처리 하였고, $\mathrm{p}<0.05$ 수준으로 Duncan's multiple range test에 의 하여 data 상호간의 유의성을 검정하였다.

\section{결과 및 고찰}

\section{양념소스의 일반성분}

발효액 첨가량에 따른 양념육 소스의 일반성분을 분석한 결과는 Table 1 과 같다. 수분함량은 대조구에서 $41.6 \%$ 로 가장 낮게 나타났고, 발효액 첨가량이 증가함에 따라 수분 함량은 증가하였다. 조단백질과 조지방 함량 그리고 조회 분 함량은 대조구에 비해 발효액 첨가량이 증가함에 따라 다소 감소하였다. 이는 발효액의 수분함량이 높아 첨가량 에 비례하여 소스의 수분함량은 증가하였고 기타 성분의 함량은 감소하였다고 판단된다. Nam 등(11)은 오미자 즙 첨가량 증가에 따라 불고기소스의 조회분 함량은 유의적으 로 감소한다고 하였고, $\operatorname{Kim}(20)$ 은 복분자 엑기스 첨가량이 증가함에 따라 소스의 수분함량은 증가하고, 조단백질, 조

Table 1. Compositions of meat seasoning sauces added with fermented Oenothra biennis juice

\begin{tabular}{ccccc}
\hline \multirow{2}{*}{ Composition } & \multicolumn{4}{c}{ Concentration of fermented } \\
\cline { 2 - 5 } & 0 & 5 & 10 & 15 \\
\hline Moisture & 41.6 & 41.8 & 43.1 & 44.9 \\
Crude protein & 2.8 & 2.8 & 2.5 & 2.3 \\
Crude fat & 3.6 & 3.5 & 3.4 & 3.2 \\
Crude ash & 4.8 & 4.8 & 4.5 & 4.3 \\
Carbohydrate & 47.2 & 47.1 & 46.5 & 45.3 \\
\hline Total & 100 & 100 & 100 & 100 \\
\hline
\end{tabular}

지방, 조회분은 감소하였다는 보고와 본 연구결과는 일치 하였다.

\section{소스의 이화학적, 미생물학적 특성}

발효액을 첨가한 양념육 소스의 이화학적 특성은 Table 2 에 나타내었다. $\mathrm{pH}$ 는 대조구가 5.37 , 발효액 $5 \%$ 첨가구 (5.35)는 대조구와 유사하였으며, 첨가량 증가에 따른 뚜렷 한 변화는 나타나지 않았다. 산도 역시 $\mathrm{pH}$ 의 변화와 유사한 경향을 나타내었다. 당도는 대조구가 $50.50{ }^{\circ} \mathrm{Brix}$, 발효액 $10 \%$ 첨가구 $\left(50.0{ }^{\circ} \mathrm{Brix}\right)$ 까지는 뚜렷한 변화는 없었으나 $15 \%$ 첨가구의 경우 $49.67{ }^{\circ} \mathrm{Brix}$ 로 뚜렷이 감소하였다. 이러 한 결과는 Lee 등(12)의 당귀 당 추출액과 매실 염절임액을 첨가한 불고기소스의 결과와 유사하였다. 발효액 첨가에 따른 양념육 소스의 glucose 함량은 대조구 $4.97 \mathrm{mg} \%$, 발효 액 첨가구는 $11.81 \mathrm{mg} \%(5 \%), 16.88 \mathrm{mg} \%(10 \%), 25.90$ $\mathrm{mg} \%(15 \%)$ 로 증가하였다. Fructose 함량은 대조구가 44.27 $\mathrm{mg} \%$ 로 가장 높게 측정되었으며 달맞이꽃 발효액 $5 \%$ 첨가 구가 $10.91 \mathrm{mg} \%$ 로 가장 낮게 측정되었다. Sucrose 함량은 대조구에서는 검출되지 않았으며, 설탕용액으로 제조한 발 효액(15)의 첨가 비율이 증가함에 따라 sucrose 함량도 증가 하는 경향을 나타내었다. Maltose 함량은 모든 실험구에서 검출되지 않았다.

양념육 소스의 색도는 발효액 첨가량이 증가할수록 $\mathrm{L}$, $\mathrm{a}, \mathrm{b}$ 값은 감소하는 경향을 나타났다. 이러한 결과는 Kim (21)의 매실 원액 첨가량에 따른 불고기 양념소스의 $\mathrm{L}, \mathrm{a}$, $\mathrm{b}$ 값이 감소하였다는 결과와 유사하였다.

발효액 첨가 양념육 소스의 DPPH radical 소거능은 대조 구 $25.66 \%$, 발효액 첨가구는 $31.83 ~ 40.91 \%$ 로 발효액 첨가 에 따라 유의적으로 증가하였다( $\mathrm{p}<0.05)$. 이러한 결과는 달 맞이꽃 발효액의 polyphenol류 함량 및 DPPH radical 소거 능(15)에 기인한 것으로 판단된다.

발효액 첨가 양념육 소스의 지방산패 억제능(TBARS)은 대조구 $19.27 \%$ 에 비해, 발효액 $5 \%, 10 \%, 15 \%$ 첨가구는 각각 $21.89 \%, 23.46 \%, 24.66 \%$ 를 나타내어 대조구에 비해 증가하였다 $(\mathrm{p}<0.05)$. 이러한 결과는 달맞이꽃에 함유되어 있는 다량의 linoleic acid, $\gamma$-linolenic acid 및 oleic acid와 같은 강력한 항산화 효과를 나타내는 여러 성분(14)에 기인 된 것으로 판단된다. 육제품은 저장 및 조리 가공 중에 지방 산화로 인해 형성된 과산화물이나 각종 2 차 산화물에 의해 이취에 의한 품질저하가 발생되며 이러한 식품섭취로 인해 노화, 발암, 동맥경화 등의 질병을 유발시킬 수 있어(22) 지방산화를 억제시킬 수 있는 달맞이꽃 발효액 첨가 소스는 양념육 소스로서의 가치가 충분히 있을 것으로 사료된다.

양념육 소스의 총균수는 3.35 3.70 $\log \mathrm{CFU} / \mathrm{g}$ 의 범위를 나타내어 발효액 첨가구와 대조구와의 뚜렷한 차이는 나타 나지 않았다. 대장균군은 모든 실험구에서 검출되지 않 았다. 
발효액 첨가 양념육 소스의 관능검사

달맞이꽃 발효액 첨가량을 달리한 양념육 소스의 기호성 은 Table 3 에서 보는 바와 같다. 맛과 색은 발효액 $5 \%$ 첨가 구가 4.23으로 가장 높은 기호도를 나타내었다. 풍미는 대 조구에 비해 발효액 첨가구가 기호성이 우수하였으며, 종 합적기호도는 $5 \%$ 첨가구가 4.15 로 가장 높아 달맞이꽃 발 효액 $5 \%$ 첨가한 양념육 소스의 기호성이 가장 우수하였다. 양념육 소스 제조시 달맞이꽃 발효액을 첨가할 경우 항산화 활성, 지방산패 억제능 등의 기능성과 기호성이 개선될 수 있는 적정 농도는 $5 \%$ 에서 $10 \%$ 범위가 타당할 것으로 판단 된다. $10^{\circ} \mathrm{C}$ 에서 25 일간 저장하면서 $\mathrm{pH}$ 및 적정산도의 변화를 측 정한 결과는 Fig. 1 과 같다.

일반적으로 $\mathrm{pH}$ 는 미생물의 생육에 영향을 미치며, $\mathrm{pH}$ 의 변화에 따라 미생물군도 변화하므로 소스에 있어서 $\mathrm{pH}$ 의 변화는 숙성상태를 간접적으로 알 수 있는 자료가 된다. 제조 당일 양념육 소스의 $\mathrm{pH}$ 는 대조구가 5.35로 가장 높았 으나, 발효액의 첨가량이 증가함에 따라 $\mathrm{pH}$ 는 낮아지는 경향을 나타내어 5.35 5.21의 범위를 나타내었다. 저장기 간 동안 대조구의 $\mathrm{pH}$ 는 증가하는 경향을 나타내었지만 달 맞이꽃 발효액을 첨가한 처리구에서의 저장 전 기간 동안 $\mathrm{pH}$ 는 뚜렷한 변화를 나타나지 않았다. 이러한 결과는 Kum

Table 2. Physicochemical and microbiological properties of meat seasoning sauce added with fermented Oenothra biennis juices at various concentrations

\begin{tabular}{|c|c|c|c|c|c|}
\hline \multirow{2}{*}{\multicolumn{2}{|c|}{ Contents }} & \multicolumn{4}{|c|}{ Concentration of fermented Oenothra biennis juice (\%) } \\
\hline & & 0 & 5 & 10 & 15 \\
\hline \multicolumn{2}{|c|}{$\mathrm{pH}$} & $5.37 \pm 0.02^{\mathrm{al})}$ & $5.35 \pm 0.01^{\mathrm{a}}$ & $5.27 \pm 0.01^{\mathrm{b}}$ & $5.23 \pm 0.02^{\mathrm{c}}$ \\
\hline \multicolumn{2}{|c|}{ Titratable acidity $(\%)$} & $0.58 \pm 0.01^{b}$ & $0.59 \pm 0.01^{b}$ & $0.59 \pm 0.01^{\mathrm{ab}}$ & $0.61 \pm 0.01^{\mathrm{a}}$ \\
\hline \multicolumn{2}{|c|}{ Saccarinity ( ${ }^{0}$ Brix $)$} & $50.50 \pm 0.50^{\mathrm{a}}$ & $50.33 \pm 0.58^{\mathrm{ab}}$ & $50.00 \pm 0.01^{\mathrm{ab}}$ & $49.67 \pm 0.12^{b}$ \\
\hline \multirow{4}{*}{ Free sugar $(\mathrm{mg} \%)$} & Glucose & 4.97 & 11.81 & 16.88 & 25.90 \\
\hline & Fructose & 44.27 & 10.91 & 14.85 & 26.03 \\
\hline & Sucrose & $\mathrm{ND}^{2)}$ & 41.56 & 46.64 & 47.46 \\
\hline & Maltose & ND & ND & ND & ND \\
\hline \multirow{3}{*}{ Color } & $\mathrm{L}$ & $24.44 \pm 0.01^{b}$ & $23.96 \pm 0.01^{\mathrm{d}}$ & $24.08 \pm 0.00^{c}$ & $24.50 \pm 0.03^{\mathrm{a}}$ \\
\hline & a & $8.76 \pm 0.03^{\mathrm{a}}$ & $6.67 \pm 0.02^{\mathrm{b}}$ & $6.62 \pm 0.06^{b}$ & $5.85 \pm 0.07^{\mathrm{c}}$ \\
\hline & $\mathrm{b}$ & $5.53 \pm 0.01^{\mathrm{a}}$ & $4.50 \pm 0.01^{\mathrm{c}}$ & $4.16 \pm 0.01^{\mathrm{d}}$ & $4.95 \pm 0.05^{\mathrm{b}}$ \\
\hline \multicolumn{2}{|c|}{ DPPH radical scavenging activity (\%) } & $25.66 \pm 0.25^{\mathrm{c}}$ & $31.83 \pm 1.30^{b}$ & $36.34 \pm 1.30^{b}$ & $39.21 \pm 1.76^{\mathrm{a}}$ \\
\hline \multicolumn{2}{|c|}{ TBARS $(\%)$} & $19.27 \pm 0.25^{\mathrm{c}}$ & $21.89 \pm 0.25^{\mathrm{b}}$ & $23.46 \pm 0.67^{\mathrm{ab}}$ & $24.66 \pm 1.72^{\mathrm{a}}$ \\
\hline \multicolumn{2}{|c|}{ Total bacteria (CFU/g) } & $3.35 \pm 0.09^{b}$ & $3.52 \pm 0.08^{\mathrm{ab}}$ & $3.55 \pm 0.06^{\mathrm{ab}}$ & $3.70 \pm 0.20^{a}$ \\
\hline \multicolumn{2}{|c|}{ Coliform bacteria (CFU/g) } & ND & ND & ND & ND \\
\hline
\end{tabular}

${ }^{1)}$ Means within each row with no common superscripts are significantly different $(p<0.05)$.

${ }^{2)}$ Not detected.

Table 3. Sensory evaluation of meat seasoning sauce added with fermented Oenothra biennis juices at various concentrations

\begin{tabular}{|c|c|c|c|c|}
\hline \multirow{2}{*}{ Sensory properties } & \multicolumn{4}{|c|}{ Concentration of fermented Oenothra biennis juice (\%) } \\
\hline & 0 & 5 & 10 & 15 \\
\hline Taste & $3.69 \pm 0.75^{1 \mathrm{ab} 2)}$ & $4.23 \pm 0.73^{\mathrm{a}}$ & $3.85 \pm 0.80^{\mathrm{ab}}$ & $3.23 \pm 0.93^{\mathrm{bc}}$ \\
\hline Color & $3.46 \pm 0.52^{\mathrm{ab}}$ & $3.85 \pm 0.69^{\mathrm{a}}$ & $3.54 \pm 0.66^{\mathrm{ab}}$ & $3.23 \pm 0.44^{\text {bc }}$ \\
\hline Flavor & $3.15 \pm 0.55^{\mathrm{a}}$ & $3.62 \pm 0.87^{\mathrm{a}}$ & $3.62 \pm 0.87^{\mathrm{a}}$ & $3.46 \pm 0.66^{\mathrm{a}}$ \\
\hline Overall acceptability & $3.69 \pm 0.63^{\mathrm{ab}}$ & $4.15 \pm 0.80^{\mathrm{a}}$ & $3.92 \pm 0.86^{\mathrm{ab}}$ & $3.31 \pm 0.85^{\mathrm{bc}}$ \\
\hline
\end{tabular}

\footnotetext{
${ }^{1)}$ Each value is expressed as the mean \pm SD $(n=20)$.

${ }^{2)}$ Means within each row with no common superscripts are significantly different $(\mathrm{p}<0.05)$.
}

\section{소스의 저장 중 $\mathrm{pH}$ 및 산도의 변화}

발효액 $5 \%, 10 \%, 15 \%$ 를 첨가하여 제조한 양념육 소스를
과 $\operatorname{Han}(23)$ 의 된장과 고추장을 이용한 전통 양념 소스의 제조시 저장기간이 경과함에 따라 큰 변화는 없었다는 보고 와 유사한 경향을 나타내었다.

일반적으로 산도는 원료 및 발효과정 중 미생물의 대사 작용으로 생성되는 유기산의 증가로 $\mathrm{pH}$ 가 저하되고 아울 러 산도가 증가하게 되는데 본 연구에서는 숙성기간에 따른 $\mathrm{pH}$ 의 변화가 적어, 산도는 저장 초기수준 $(0.6 \%)$ 을 유지하 였다.

\section{저장 중 미생물의 변화}

소스의 저장 중 미생물의 성장은 소스의 품질에 중요한 영향을 미친다. 발효액 첨가 양념육 소스를 $10^{\circ} \mathrm{C}$ 에서 25 일 간 저장하면서 대조구와 총균수의 변화를 비교한 결과(Fig. 

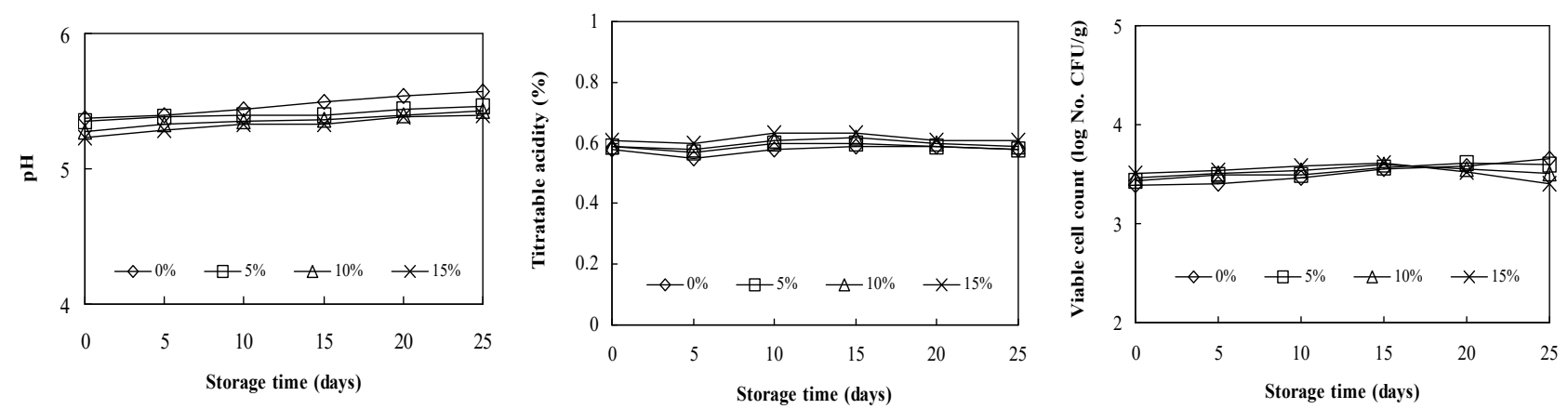

Fig. 1. Changes in $\mathrm{pH}$, titratable acidity and viable cell count of meat seasoning sauces added with fermented Oenothra biennis juice at various concentrations during storage for 25 days at $10^{\circ} \mathrm{C}$.

1) 저장초기 저장 양념육 소스의 총균수는 대조구와 발효액 첨가구간의 뚜렷한 차이는 없었으며 3.35 3.69 $\log \mathrm{CFU} / \mathrm{g}$ 범위를 나타내었고, 저장기간 동안 급격한 증가현상은 관 찰되지 않았다. 저장 25 일째에 총균수는 $3.62 ~ 3.83 \log$ $\mathrm{CFU} / \mathrm{g}$ 의 범위를 나타내었다. 저장기간 중 대장균군 측정 결과 모든 처리구에서 검출되지 않았다. Park 등(24)의 데리 야끼소스를 제조하여 총균수를 측정한 결과 균이 거의 나타 나지 않은 이유가 소스의 제조방법에 가열처리에 기인된 것이라 보고한 바 있다.

항염작용을 비롯한 고혈압, 항균, 항암과 같은 여러 활성 을 나타낸다고 알려져진 달맞이꽃을 이용하여 제조한 발효 액을 양념육 소스의 소재로 활용가능성을 검토한 결과 발효 액 $5 \%$ 에서 $10 \%$ 범위로 첨가한 경우 기호성 면에서 가장 우수하였고, 이를 첨가한 경우 항산화 활성 및 지방산패 억제능 개선은 물론 저장 중 품질유지가 가능하여 양념육소 스의 소재로 활용이 가능할 것으로 판단된다. 상용화에 앞 서 양념육의 기호성 및 품질에 미치는 영향과 소스의 위생 적인 제조공정에 관한 보다 광범위한 연구가 선행되어야 할 것으로 판단된다.

\section{요 약}

달맞이꽃 발효액의 식품소재로서의 활용방안을 모색하 기 위하여, 달맞이꽃 발효액을 이용한 양념육 소스의 제조 가능성을 검토하였다. 발효액을 각각 $5 \%, 10 \%, 15 \%$ 첨가한 양념육 소스의 $\mathrm{pH}$ 는 5.23 5.37을 나타내었고, 유리당 함량 은 첨가량이 증가할수록 증가하였으며, 색도는 $\mathrm{L}, \mathrm{a}, \mathrm{b}$ 값 모두 발효액 첨가가 증가할수록 감소하였다. DPPH 라디칼 소거능과 지방산패억제능은 발효액 첨가가 증가할수록 증 가하였으며, 총균수는 3.35 3.69 $\log \mathrm{CFU} / \mathrm{g}$ 의 범위를 나타 내었으나, 대장균군은 검출되지 않았다. 관능검사 결과 발 효액 $5 \%$ 첨가 양념육 소스가 맛, 색 그리고 종합적 기호도에 서 가장 우수하였다. 발효액첨가 양념육 소스의 $10^{\circ} \mathrm{C}$ 에서
25 일간 저장 기간중 소스의 $\mathrm{pH}$ 는 뚜렷한 변화를 나타나지 않았으며, 산도 역시 저장 초기수준( $0.6 \%)$ 을 유지하였다. 저장기간 동안 총균수는 급격한 증가현상은 관찰되지 않아 저장 25 일째에 총균수는 $3.62 ~ 3.83 \log \mathrm{CFU} / \mathrm{g}$ 의 범위를 나 타내었다. 저장기간 중 대장균군은 모든 처리구에서 검출 되지 않았다.

\section{References}

1. Choi SK, Choi HS, Lee JS (2001) The characteristics of brown stock prepared by high pressure cooking. J East Asian Soc Dietary Life, 11, 281-288

2. Lim KR, Kim KY, Choi SK, Kim YS, Lee KH (2010) Characteristics of brown sauce made with various amount of Chungkukjang powder. J East Asian Soc Dietary Life, 20, 263-271

3. Korean Food \& Drug Administration (2002) Food code. Munyoungsa, Seoul, Korea, p 212-213

4. Oh DH (1986) Studies on the quality of cured meat in the processing. $\mathrm{Ph} \mathrm{D}$ Thesis, Chonbuk National University, Korea, p 34-38

5. Minussi RC, Rossi M, Bologna L, Cordi L, Rotilio D, Pastore GM, Duran N (2003) Phenolic compounds and total antioxidant potential of commercial wines. Food Chem, 82, 409-416

6. Montesinos-Herrero C, del Rio MA, Pastor C, Brunetti O, Palou L (2009) Evaluation of brief potassium sorbate dips to control postharvest Penicillium decay on major citrus species and cultivars. Postharvest Biol Technol, 52, $117-125$

7. Cassen RG (1995) Use of sodium nitrite in cured meats today. Food Technol, 49, 72-80

8. Shahidi F, Janita PK, Wanasundara PD (1992) Phenolic 
antioxidants. Crit Rev Food Sci Nutr, 32, 67-103

9. Lee SH, Jeong EJ, Jung TS, Park LY (2009) Antioxidant activities of seasoning sauces prepared with Geranium thunbergii sieb. et Zucc. and Crataegi fructus and the quality changes of seasoned pork during storage. Korean J Food Sci Technol, 41, 57-63

10. Cho JL, Lee SC, Kim JM (2011) Quality characteristics of Bulgogi marinade prepared with mulberry. J Korean Soc Food Sci Nur, 40, 1589-1596

11. Nam JS, Choi Sk, Kim DS (2010) Quality and sensory characteristics of Bulgogi sauce with various amount of Omija extract juice. Korean J Culinary Res, 16, 247-259

12. Lee SH, Park ML, Lee SH, Kim HR, Choi SK, Choi SH (2010) Quality characteristics of Bulgogi seasoning sauce prepared with Angelica gigas Nakai extract and salted liquid of Prunus mume. Korean J Culinary Res 16, 247-263

13. Park SW, Byun GI (2014) Development of Bulgogi sauce added with concentrated Curcuma longa L.. Korean J Culinary Res, 20, 143-158

14. Taniguchi S, Imayoshi Y, Yabu-uchi R, Ito H, Hatano $\mathrm{T}$, Yoshida $\mathrm{T}$ (2002) A macrocylic ellagitannin trimer, oenotherin $\mathrm{T}_{1}$, from Oenothera species. Phytochemistry, 59, 191-195

15. Ahn YB, Kang KM, Kim JH, Park LY, Lee SH (2015) Quality characteristics of Oenothera biennis juice fermented at different temperatures and sugar concentrations. J Korean Soc Food Sci Nutr, 44, 746-751
16. Kim IS, Jin SK, Kang SN, Hur IC, Choi SY (2009) Effect of olive-oil prepared tomato powder (OPTP) and refining lycopene on the physicochemical and sensory characteristics of seasoned raw pork during storage. Korean J Food Sci Ani Resour, 29, 334-339

17. AOAC (1995) Official Methods of Analysis. 16th ed, Association of Official Analytical Chemists, Washington DC, USA, p 69-74

18. Blois MS (1958) Antioxidant determinations by the use of a stable free radical. Nature, 181, 1199-1200

19. Buege JA, Aust SD (1978) Microsomal lipid peroxidation. Methods Enzymol, 52, 302-310

20. Kim HS (2007) A study on the effect of Rubus coreanus Miquel on the taste of Demi-glace based sauce. MS Thesis, Woosong University, Korea, p 19-45

21. Kim IS (2007) A study on the consumers' use of processed food of Prunus mume and development of processed food. MS Thesis, Yeungnam University, Korea, p 59-73

22. Sung NJ (2000) Formation of cholesterol oxidation products in foods. Food Industry and Nutrition, 5, 10-20

23. Kum JS, Han O (1997) Changes in physicochemical properties of Kochujang and Doenjang prepared with extrudated wheat flour during fermentation. J Korean Soc Food Sci Nutr, 26, 601-605

24. Park SY, Chin KB (2007) Evaluation of antioxidant activity in pork patties containing Bokbunja (Rubus coreanus) extract. Korean J Food Sci Ani Resour, 27, 432-439 